\title{
WATER RETENTION IN A RHODIC KANDIUDOX UNDER ANIMAL MANURE APPLICATION AFTER 20 CONSECUTIVE YEARS
}

\author{
Andreia Patrícia Andrade ${ }^{1}$, Luiz Paulo Rauber ${ }^{2}$, Diego Bortolini ${ }^{3}$, Ana Cláudia Casara ${ }^{4}$, Myrcia \\ Minatti $^{5}$; Álvaro Luiz Mafra ${ }^{1}$; Letícia Sequinatto ${ }^{1}$
}

\footnotetext{
${ }^{1}$ Santa Catarina State University. Professor. E-mail: andreiapatricia74@yahoo.com.br; alvaro.mafra@udesc.br; letisequinatto@gmail.com

${ }^{2}$ University of West Santa Catarina. Professor. E-mail: lprauber@gmail.com

${ }^{3}$ Santa Catarina State University. PhD Student. E-mail: diegobertanbortolini@gmail.com

${ }^{4}$ Santa Catarina State University. Scholarship holder. E-mail: aninhacasara@ hotmail.com

${ }^{5}$ Santa Catarina State University. Forest Engineering Master Degree Student. E-mail: mirciaminatti@ gmail.com
}

\section{ABSTRACT}

The use of animal manure may improve structure and increase water retention and availability in the soil. This study evaluated the effect of manure application for 20 years on water storage and availability in a Rhodic Kandiudox. The treatments consisted of different soil use and management systems with application of swine and poultry manure, as follows: i) corn crop (C20); ii) pasture crop (P20); iii) mate (M20); and iv) native forest (NF). The soil samples were collected in the depths $0.00-0.05,0.05-0.10$ and $0.10-0.20 \mathrm{~m}$, in the inter row position. Manure application in the corn and mate areas reduced soil porosity, influencing the availability of water, where there is a higher water storage at field capacity and permanent wilting point. Water retention was influenced by TOC in the managed areas with manure addition.

Keywords: Clayed soil, pore diameter, water retention curve

\section{RETENÇÃO DE ÁGUA EM NITOSSOLO VERMELHO COM APLICAÇÃO DE ESTERCO DE ANIMAIS DURANTE 20 ANOS CONSECUTIVOS}

\section{RESUMO}

$\mathrm{O}$ uso de estercos pode favorecer a estrutura e aumentar a retenção e disponibilidade de água no solo. Neste estudo avaliou-se o efeito de 20 anos de aplicação de estercos sobre o armazenamento e a disponibilidade de água num Nitossolo Vermelho. Os tratamentos abrangeram diferentes sistemas de uso e manejo do solo com aplicação de esterco de suínos e de aves, sendo: 
i) cultura do milho; ii) pastagem; iii) cultura da erva mate e iv) mata nativa. As amostras de solo foram coletadas em anéis volumétricos nas camadas 0.00-0.05, 0.05-0.10 e 0.10-0.20 m, nas entrelinhas de plantio. A aplicação de estercos nas áreas com cultivo de milho e erva mate diminuíram a porosidade do solo, influenciando a disponibilidade de água, onde foi observado maior armazenamento de água na capacidade de campo e ponto de murcha permanente. A retenção de água foi influenciada pelo COT nas áreas manejadas com adição de estercos.

Palavras chave: Solo argiloso, diâmetro de poros, curva de retenção de água

\section{INTRODUCTION}

Swine and poultry farming is an important agriculture activity in Santa Catarina, southern Brazil. This activity results in a large volume of manure, usually applied in crops and pasture areas. However, environmental problems in this region can be intensified due to successive and broadcasting applications of swine (SM) and poultry (PM) manure, in moderate to steep slope conditions (SCHERER, et al., 2010).

In addition, the western region of Santa Catarina had its milk production increased, which may lead to changes in the soil due to the presence of animals in direct grazing, resulting in compaction, which is reflected on the retention, movement and availability of water in the soil. On the other hand, one way to improve the structural quality of the soil in these areas is through its conservation and addition of organic matter, such as the addition of animal manures, which results in an increase in pore volume, promoting infiltration and water storage in the soil (SHI et al., 2012).

Several studies show the influence of the application of animal manure on the attributes related to soil structure. By evaluating physical properties and soil organic carbon in areas submitted to the application of swine manure and poultry litter, Barbosa et al. (2015) verified an increase in the porosity and a decrease in the density of an Oxisol. Hati et al. (2006), when studying a Vertisol with the addition of animal manure, observed an increase in aggregate stability and porosity, which enhanced the efficiency in water use by the plants. However, there are reports in the literature showing that the improvement depends on the time, frequency and amount of manure application, besides the type of the management used in the areas (OLIVEIRA et al., 2015).

Thus, the possible structural changes in the soil caused by the application of manure may influence soil water dynamics. The objective of this work was to evaluate the effect of 20 years of 
application of swine and poultry manures in different systems of soil use and management on water retention and the pore diameter in a Rhodic Kandiudox soil.

\section{MATERIAL AND METHODS}

The study was carried out in Concórdia, Santa Catarina State, Brazil, on a Rhodic Kandiudox, with sloping relief located at coordinates $27^{\circ} 18^{\prime} 78^{\prime \prime} \mathrm{S}$ and $51^{\circ} 59^{\prime} 02^{\prime}$ 'W. The climate is humid subtropical mesothermic (Cfa) according to the Köppen classification. Areas with similar conditions in terms of soil depth, slope, and texture were selected, based on the moist soil color (10R 3/6) observed in all soil samples in the $0-0.20$ m layer.

The evaluated experimental area was conducted with different systems of soil use, including cultivation forms with different crops and soil preparation forms. The studied areas did not receive any type of mineral fertilization, only swine and poultry manure for a period of 20 consecutive years. The clay content of the soil is $499 \mathrm{~g} \mathrm{~kg}^{-1}$. In the conventional tillage soil receives a plowing and two gradations.

The experimental design was completely randomized, based on the existence of pseudorepetitions, and it was verified the homogeneity of variance with data given the normal distribution (FERREIRA et al., 2012).

Soil use and management systems, with application of animal manures in the form of swine slurry (SS) and poultry litter (PL), are described as follows: i) corn for silage with two annual crops and cultivation of ryegrass in winter, with dairy cattle grazing; conventional soil tillage and 20 years of application of manure before corn and pasture sowing (C20); ii) annual pasture with oats/ryegrass/fodder radish intercropped in winter and summer fallow; with no soil tillage and grazing, with annual cutting and 20 years of manure application (P20); iii) mate with 20 years of manure application between rows of the trees and with no soil tillage (M20); and iv) native forest with no anthropic interference (NF).

Poultry litter was applied once a year, at a rate of $16 \mathrm{~m}^{3} \mathrm{ha}^{-1}$, while SS was applied every three months, in all evaluated areas except NF. Swine manure was applied in the liquid form, with a tractor on the soil surface, with an annual rate of $50 \mathrm{~m}^{3} \mathrm{ha}^{-1}$, following the current recommendation at the time (FATMA, 2000). The estimated carbon input for the 20 years of application was $46 \mathrm{Mg} \mathrm{ha}^{-1}$, considering the SS (density $1.014 \mathrm{~g} \mathrm{~L}^{-1}$, carbon concentration of $9 \%$ 
and dry mass of $3 \%$ ) and PL (density $0.29 \mathrm{~g} \mathrm{~L}^{-1}$, carbon concentration of $30 \%$ and $75 \%$ of dry mass), according to data obtained from Scherer et al. (1995).

Soil samples were collected in volumetric rings of $0.05 \mathrm{~m}$ in diameter and $0.025 \mathrm{~m}$ in height in the depths of $0.00-0.05,0.05-0.10$ and $0.10-0.20 \mathrm{~m}$. For all areas, sampling procedure was performed in a systematic way, with eight replicates in two transects with points spaced by 10 meters in each area, located in the inter row position.

The analyzes carried out were soil density (SD), porosity, total organic carbon (TOC), water retention curve in the soil, pore diameter class and unsaturated hydraulic conductivity. The analyzes of SD and particle density (PD) were performed using the methodology described in Embrapa (1997). The volume of biopores (Bio) and micropores (Micro) was determined on a sand table at 1 and $6 \mathrm{kPa}$ matric potential, respectively. Total porosity (TP) was calculated by the ratio between soil density and particle density. Macroporosity (Macro) was obtained by the difference between TP and Micro.

For the analysis of total organic carbon (TOC), samples were collected in the three layers at 10 points (sub-samples) near the site of ring collections, using a cutting shovel. The soil was homogenized, resulting in a composite sample, and analyzed according to the methodology described by Tedesco et al. (1995).

The water retention curve (WRC) was determined by applying the tensions of 1, 6 and 10 $\mathrm{kPa}$ on a sand tension table, and 33,100,300, 500 and 1,500 kPa in a Richards chamber. Water retention capacity was adjusted using the water content in volumetric basis using the Van Genuchten model (1980), applying the Soil Water Retention Curve (SWRC) software (DOURADO NETO et al., 1990), according to equation 1:

$$
\theta=\theta r+\frac{(\theta s-\theta r)}{\left(1+\left(\alpha \psi_{m}\right)^{n}\right)^{m}}
$$

Where: $\theta=$ soil volumetric water content $\left(\mathrm{m}^{3} \mathrm{~m}^{-3}\right) ; \theta \mathrm{r}=$ residual volumetric water content $\left(\mathrm{m}^{3} \mathrm{~m}^{-}\right.$ $\left.{ }^{3}\right) ; \theta \mathrm{s}=$ saturated volumetric water content $\left(\mathrm{m}^{3} \mathrm{~m}^{-3}\right) ; \psi \mathrm{m}=$ matric potential $(\mathrm{kPa}) ; \alpha \mathrm{n}, \mathrm{m}=$ empirical parameters.

The amount of available water was estimated by the difference between the volumetric water content at $10 \mathrm{kPa}$, referred to as field capacity and $1,500 \mathrm{kPa}$, considered as permanent wilting point (CARLESSO, 1995). 
To estimate the saturated hydraulic conductivity of the water in unsaturated soil, the Mualen criterion was used, where $m=(1-(1 / n)$, followed by equation 1 :

Pore volume was calculated for the suctions intervals between 0-1, 1-6, 6-10, 10-100, 1001,500; and < 1,500 kPa, respectively, corresponding to the following pore diameter classes: $>300$, 50-300, 30-50, 3-30, 0.2-3; and <0.2 $4 \mathrm{~m}$. To obtain each pore diameter, equation 2 was used:

$$
r=\frac{2 \cdot \sigma \cdot \cos \alpha}{\rho \cdot g \cdot h}
$$

Where: $r=$ pore radius $(\mathrm{m}) ; \sigma=$ liquid surface tension $\left(0.0728 \mathrm{~N} \mathrm{~m}^{-1}\right.$ at $\left.20{ }^{\circ} \mathrm{C}\right) ; \rho=$ liquid density $\left(1.000 \mathrm{~kg} \mathrm{~m}^{-3}\right) ; \alpha=$ liquid-solid contact angle $\left(\mathrm{rad}=0^{\circ}\right) ; \mathrm{g}=$ gravity acceleration $\left(9.81 \mathrm{~m} \mathrm{~s}^{-2}\right)$; $\mathrm{h}=\operatorname{suction}(\mathrm{m})$.

By using parameters $\alpha$ and n of Van Genuchten's model, water hydraulic conductivity in unsaturated soil was estimated by using the equation 3 :

$$
\mathrm{Kr}=\mathrm{Ks} \frac{\left[1-(\alpha \psi)^{(\mathrm{n}-1)} \cdot\left(1+(\alpha \psi)^{\mathrm{n}}\right)^{-\mathrm{m}}\right]^{2}}{\left[1+(\alpha \psi)^{\mathrm{n}}\right]^{\mathrm{m} / 2}}
$$

Where: $\mathrm{Kr}=$ relative hydraulic conductivity; $\mathrm{Ks}=$ unsatured hydraulic conductivity and $\alpha \mathrm{n}, \mathrm{m}$, $\psi=$ empirical parameters.

The results were submitted to analysis of variance by the $\mathrm{F}$ test, considering a completely randomized model, with evaluation of the joint effect (application of swine and poultry manures and soil use) of treatments in each layer and comparison of means by the " $\mathrm{t}$ " test $(\mathrm{P}<0.05)$. Pearson's correlations between carbon content, matric potentials and pore diameter were estimated considering all the three sampled layers.

\section{RESULTS AND DISCUSSION}

\section{Total organic carbon}

Total organic carbon (TOC) concentrations decreased in the cultivated areas compared to the native forest (NF), in the three evaluated layers (Table 1). In the $0.00-0.05 \mathrm{~m}$ layer, the lowest TOC content was observed in C20 in relation to the other areas where manure was added. In the 0.05 - $0.10 \mathrm{~m}$ layer, no difference was observed among treatments, and NF showed the highest TOC content. In the $0.10-0.20 \mathrm{~m}$ layer, the highest TOC content among treatments that received 
manures was observed in P20. Scherer et al. (2010) did not observe any changes in the organic carbon contents, after 15 and 20 years of swine manure addition in Latosol and Cambisol under no-tillage system in relation to the native forest. Agne and Klein (2014) also did not observe the increase of organic matter when applying doses $240 \mathrm{~m}^{3} \mathrm{ha}^{-1}$ of liquid swine manure in a Red Latosol, and related this to the fact that the residue is applied in the liquid form, and consequently contain high amount of water.

The treatment M20, which had high removal of biomass by corn silage and low input due to the animal grazing during the winter, did present the lowest levels of TOC. The EM20 and P20 systems had higher levels of carbon in the superficial layer, in relation to the M20, agreeing with Portugal et al. (2008) who state that more conservationist systems tend to increase soil organic matter on the surface over time. The minimum soil disturbance, lack of incorporation of the residues and the pronounced root growth, contribute to the formation of the gradient in the carbon levels from the soil surface (BORDIN et al., 2008).

Table 1. Soil density (SD), total porosity (TP), biopores (Bio), macroporosity (Macro), microporosity (Micro), total organic carbon (TOC) and available water (AW) evaluated in areas under different soil management and use systems with application of animal manure in a Rhodic Kandiudox. Concórdia - SC, Brazil.

\begin{tabular}{|c|c|c|c|c|c|c|c|}
\hline $\begin{array}{l}\text { Soil } \\
\text { Use }\end{array}$ & $\begin{array}{c}\text { SD } \\
\mathrm{g} \mathrm{cm}^{-3}\end{array}$ & $\begin{array}{c}\mathbf{T P} \\
m^{3} m^{-3} \\
\end{array}$ & $\begin{array}{c}\text { Bio } \\
m^{3} m^{-3} \\
\end{array}$ & $\begin{array}{r}\text { Macro } \\
m^{3} m^{-3}\end{array}$ & $\begin{array}{l}\text { Micro } \\
m^{3} m^{-3}\end{array}$ & $\begin{array}{l}\text { TOC } \\
g k^{-1}\end{array}$ & $\begin{array}{c}\mathbf{A W} \\
m^{3} m^{-3}\end{array}$ \\
\hline & & & & $0.05 \mathrm{~m}$ depth & & & \\
\hline $\mathrm{C} 20$ & $1.24^{\mathrm{a}}$ & $0.50 \mathrm{~b}$ & $0.02 b$ & $0.05 \mathrm{c}$ & $0.45^{\mathrm{a}}$ & $18.8 \mathrm{c}$ & $0.11 \mathrm{a}$ \\
\hline M20 & $1.15 \mathrm{~b}$ & $0.41 \mathrm{c}$ & $0.03 b$ & $0.08 \mathrm{c}$ & $0.32 b$ & $24.8 b$ & $0.12 \mathrm{a}$ \\
\hline P20 & $0.99 \mathrm{c}$ & $0.62 \mathrm{a}$ & $0.05 b$ & $0.13 b$ & $0.48^{\mathrm{a}}$ & $23.7 b$ & $0.10 \mathrm{a}$ \\
\hline \multirow[t]{2}{*}{ NF } & $0.81 \mathrm{c}$ & $0.59 \mathrm{a}$ & $0.10 \mathrm{a}$ & $0.26 \mathrm{a}$ & $0.33 b$ & $63.0 \mathrm{a}$ & $0.12 \mathrm{a}$ \\
\hline & & & & $10 \mathrm{~m}$ depth & & & -------- \\
\hline $\mathrm{C} 20$ & $1.28^{\mathrm{a}}$ & $0.49 b$ & $0.03 b$ & $0.05 \mathrm{c}$ & $0.43 b$ & $16.6 b$ & $0,10 \mathrm{~b}$ \\
\hline M20 & $1.28^{\mathrm{a}}$ & $0.37 \mathrm{c}$ & $0.02 b$ & $0.07 b c$ & $0.30 \mathrm{c}$ & $16.0 \mathrm{~b}$ & $0,10 \mathrm{~b}$ \\
\hline P20 & $1.11 \mathrm{~b}$ & $0.58 \mathrm{a}$ & $0.04 \mathrm{ab}$ & $0.10 \mathrm{~b}$ & $0.47 \mathrm{a}$ & $18.1 b$ & $0,09 b$ \\
\hline \multirow[t]{2}{*}{$\mathrm{NF}$} & $0.97 \mathrm{c}$ & $0.52 b$ & $0.06 \mathrm{a}$ & $0.22 \mathrm{a}$ & $0.30 \mathrm{c}$ & $49.3 a$ & $0,12 \mathrm{a}$ \\
\hline & $1.20^{\mathrm{a}}$ & $0,53 b$ & $0.04 a$ & $\begin{array}{l}.20 \mathrm{~m} \text { depth } \\
0.06 \mathrm{~b}\end{array}$ & $0.47 \mathrm{a}$ & $22.1 \mathrm{c}$ & ------ \\
\hline M20 & $1.21^{\mathrm{a}}$ & $0,41 c$ & $0.05 a$ & $0.09 b$ & $0.32 b$ & $21.4 \mathrm{c}$ & $0.07 \mathrm{bc}$ \\
\hline P20 & $1.14^{\mathrm{a}}$ & $0,57 \mathrm{a}$ & $0.04 \mathrm{a}$ & $0.08 \mathrm{~b}$ & $0.49 \mathrm{a}$ & $25.6 b$ & $0.06 \mathrm{c}$ \\
\hline NF & $1.02 \mathrm{~b}$ & $0,51 b$ & $0.06 a$ & $0.18 \mathrm{a}$ & $0.33 b$ & $36.6 \mathrm{a}$ & $0.09 \mathrm{a}$ \\
\hline
\end{tabular}

Corn at 20 years of application (C20), pasture at 20 years of application (P20), mate at 20 years of application (M20) of animal manure and native forest (NF). Lower case letters in the column compare the treatment. 


\section{Pore diameter classes}

The different pore diameters were influenced by soil use and management systems with the addition of SS and PL (Figure 1). Native forest presented the highest pore volume in diameters> $300 \mu \mathrm{m}$ than the other treatments in the 0.00-0.05 m layer. In the 0.00-0.10 m layer, in pores $>300$ $\mu \mathrm{m}$, NF was similar to P20, which can be explained by the management in P20, where there was no soil disturbance, machine traffic and animal trampling. This result is expected since the anthropic action is related to soil compaction (ARATANI et al., 2009) and to the increase of microporosity. In relation to the pores $<0.2 \mu \mathrm{m}$, it can be observed that in the three evaluated layers, NF showed the lowest pore volume in relation to the other areas. The M20 and C20 treatments were similar in the three layers and presented the largest volumes of pores $<0.2 \mu \mathrm{m}$. This result is related to the management of the areas, where M20 has compaction related to the traffic of the manure distribution equipment always in the same place, and in C20, the soil had been tilled, and the presence of machinery traffic for crop harvest and animal trampling in the winter pasture. When the soil aggregates rearranged, they create voids in the soil profile and consequently contribute to the soil porosity (SHI et al., 2016; ISLABÃO et al., 2016), the reduction of soil density (ARAÚJO et al., 2016) and the soil resistance to penetration (CELIK et al., 2010).

The 0.2-3.0 $\mu \mathrm{m}$ pore class, which corresponds to the available water, treatments were similar in the 0.00 - $0.05 \mathrm{~m}$ layer. The lower volumes of these pores were observed in P20 in 0.05$0.10 \mathrm{~m}$ layer and in M20 and P20 in the $0.10-0.20 \mathrm{~m}$ layer. In the 0.05 to $0.10 \mathrm{~m}$ layer, the highest available water content was in NF, similar to M20 and C20. In the 0.10-0.20 m layer, the highest water availability was in $\mathrm{C} 20$, similar to NF. This result may be attributed to the high content of TOC in NF and higher microporosity in C20 (Table 1), because the increase of micropores generates pores with dimensions and geometry that promote water retention by capillarity (RAMOS et al., 2013). 

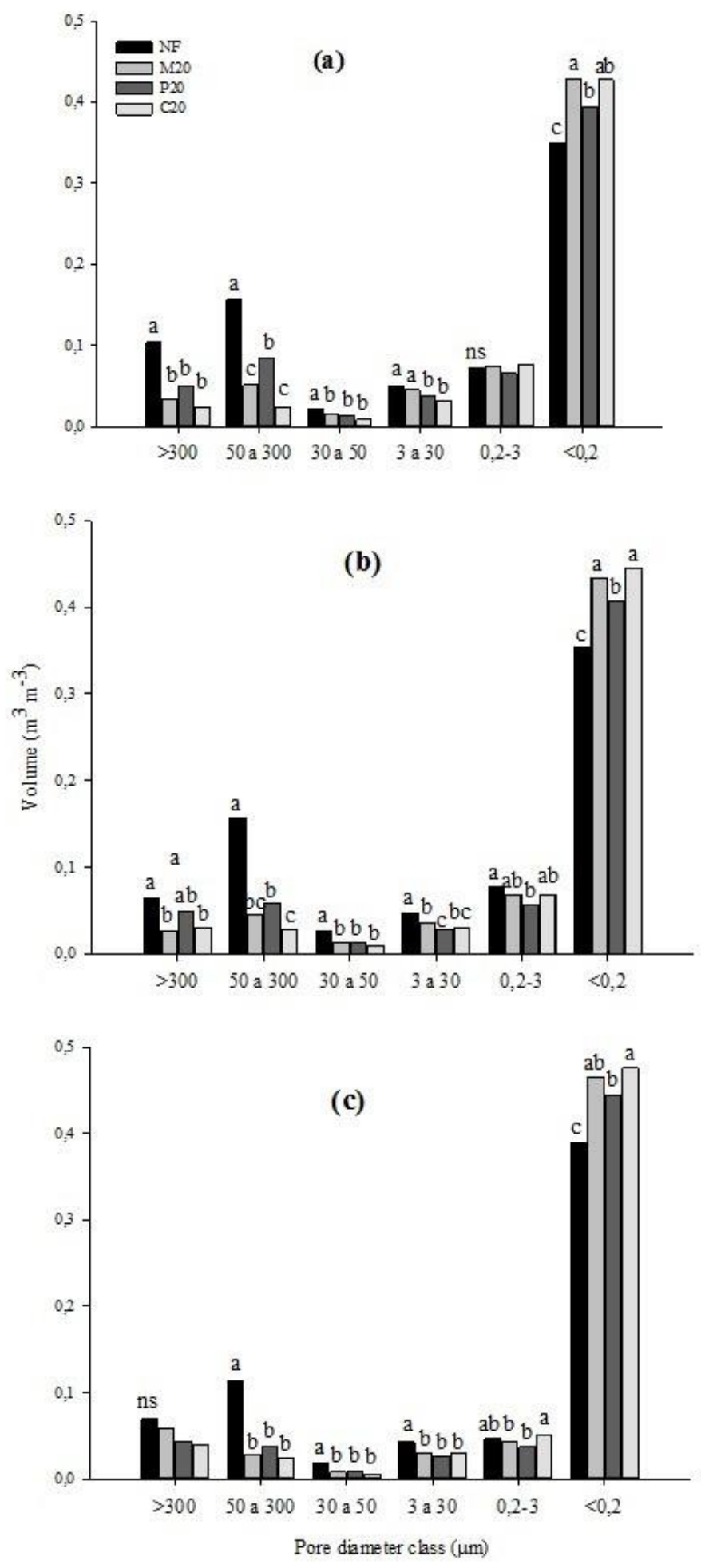

Figure 1. Classes of soil pore diameter in areas with different management and use systems at 0.00-0.05 (a), 0.05-0.10 (b) and 0.10-0.20 m layers s (c) in a Rhodic Kandiudox: corn at 20 years of application (C20), pasture at 20 years of application (P20), mate at 20 years of application (M20) of animal manure and native forest (NF). 


\section{Water retention curve in the soil}

A higher volume of water at saturation occurred in the NF in all layers, differing from the other evaluated areas (Figure 2), which may be related to a higher volume of biopores and macroporosity (Figure 1), as well as higher carbon contents in the NF. The soil water retention curves (WRC) for M20, C20 and P20 treatments presented a different form in relation to NF. In the field capacity (FC), C20 and M20 treatments presented higher water retention in the three evaluated layers, which may be related to a higher soil density (Table 1) and lower pore volume, that is, responsible for water retention. The NF and P20 treatments presented lower water retention in relation to the other treatments, both at FC and PWP in the three evaluated depths. This result can be justified by the higher volume of biopores, macroporosity and lower density, especially in NF, which positively influences the hydraulic conductivity, infiltration and better structural quality of the soil (BONO et al., 2012; ZALUSKI \& ANTONELI, 2014).

At the matric potential corresponding to the permanent wilting point (PWP), C20 and M20 treatments presented higher volumetric water content in the 0.00-0.05 m layer, while in the 0.05$0.10 \mathrm{~m}$ layer, the highest retention was achieved in C20 (Figure 2). In the 0.10-0.20 m layer, the highest water retention in PWP was observed in the three treatments that received animal manures, which may be justified by the interaction between microporosity and TOC content, which generally varied between NF and cropped areas and can be affected by soil texture.

The highest water retention in the PWP in the three layers for corn area can be related to the largest volume of micropores observed in the three layers, which was associated to biomass removal, soil tillage and animal trampling, which may have affected WRC (Figure 2). For M20, a higher water retention was found in the first layer, followed by a lower retention and an increase in the underlying layer. Such behavior of water retention over the profile is related to the higher microporosity in the upper and lower analyzed layers and to the lower value in the intermediate layer (Table 1). This differs from the $\mathrm{C} 20$ where soil was periodically tilled, which after 20 years of management may have caused compaction below the surface layer. These results show that changes in soil structure interfere in the soil water storage capacity (REICHARDT \& TIMM, 2004). 

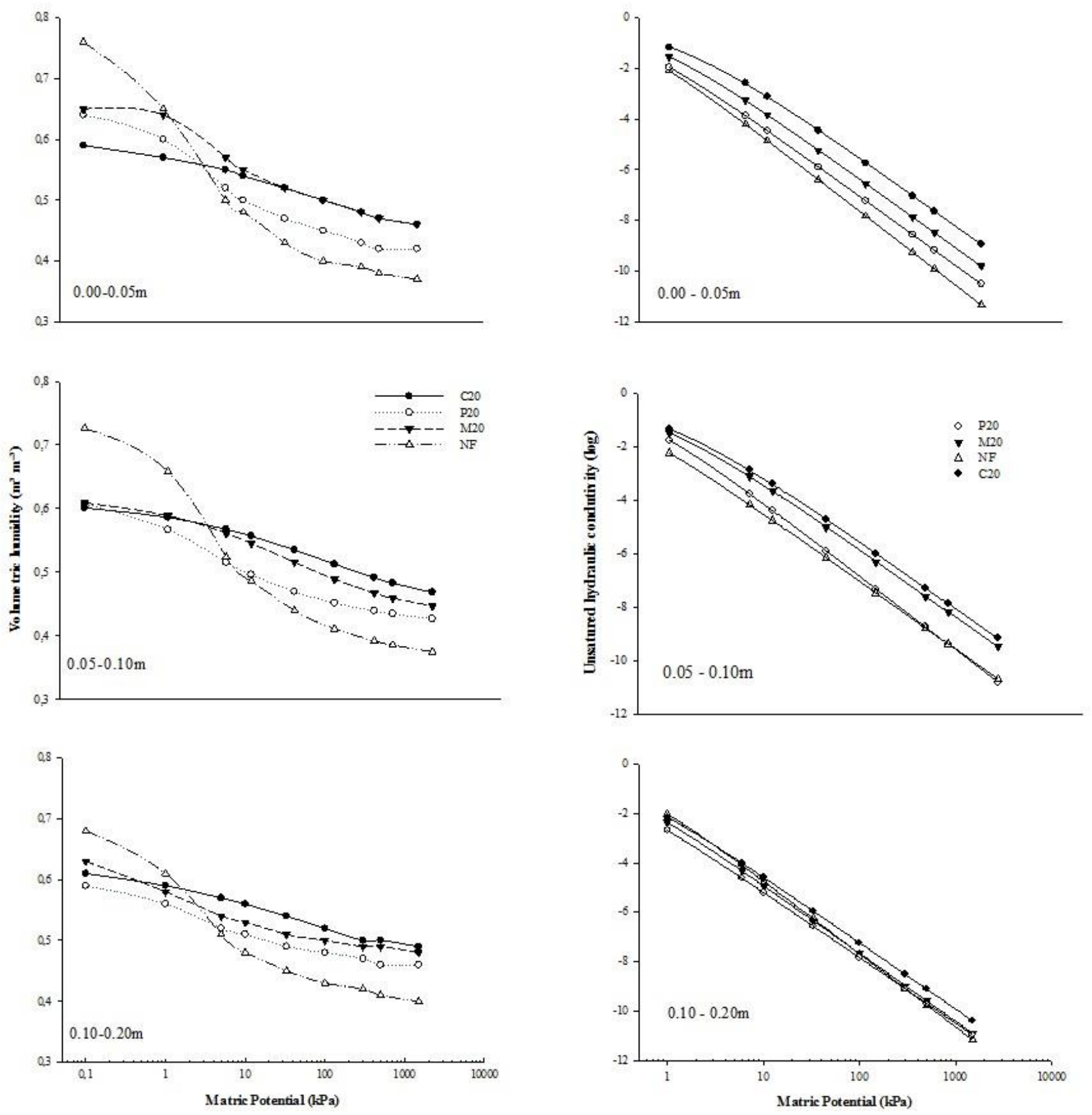

Figure 2. Water retention curves in the soil (a) and saturated hydraulic conductivity (b), in areas with different land use and management systems at the 0.00-0.05, 0.05-0.10 and 0.10$20 \mathrm{~m}$ layers in a Rhodic Kandiudox: corn at 20 years of application (C20), pasture at 20 years of application (P20), mate at 20 years of application (M20) of animal manure (M20) and native forest (NF). Vertical bars indicate the least significant difference by the " $\mathrm{t}$ " test $(\mathrm{p}<0.05)$. 
The amount of available water (Table 1) ranged from 0.06 to $0.12 \mathrm{~m}^{3} \mathrm{~m}^{-3}$, which is lower than the ideal water storage capacity in the soil which, as suggested by Reynolds et al. (2002), is between 0.15 and $0.20 \mathrm{~m}^{3} \mathrm{~m}^{-3}$.

A positive correlation was found in TOC contents and WRC (Table 2), indicating that carbon content affects water retention, with higher correlation in the tensions of 500 and $1500 \mathrm{kPa}$, with values close to 0.7 . The increase in soil organic matter also contributed to water retention since it improves soil structure and increases microporosity (ARAÚJO et al., 2004). A positive correlation between TOC and the pore diameter class between 30 and $300 \mu \mathrm{m}$ was also found. This result denotes the importance of TOC in the aggregation and maintenance of soil porosity, maintaining the connectivity between them.

Table 2. Pearson's linear correlation coefficients between total organic carbon content (TOC), matric potential and pore diameter class in areas with different systems of use and times of application of animal manure. Concórdia - SC, Brazil.

\begin{tabular}{|c|c|c|c|c|c|c|c|c|}
\hline Variable & & & & Matric p & ential $(\mathrm{k}$ & & & \\
\hline \multirow{3}{*}{ TOC } & 1 & 6 & 10 & 33 & 100 & 300 & 500 & 1500 \\
\hline & $0.58 * *$ & $0.43 * *$ & $0.54 * *$ & $0.65 * *$ & $0.65 * *$ & $0.63 * *$ & $0.68 * *$ & $0.67 * *$ \\
\hline & \multicolumn{8}{|c|}{ Pore diameter class $(\mu \mathrm{m})$} \\
\hline \multirow{2}{*}{ TOC } & $>300$ & 50 to 300 & 30 to 50 & 3 to 30 & $0.2-3$ & $<0.2$ & & \\
\hline & $0.51 * *$ & $0.81 * *$ & $0.70 * *$ & $0.53 * *$ & - & $-0.67 * *$ & & \\
\hline
\end{tabular}

**Significant at $1 \%$ of probability.

\section{Unsaturated hydraulic conductivity}

Native forest presented higher $\mathrm{Kr}$ in the two upper layers and P20 treatment was similar to it in the 0.05-0.10 m layer (Figure 2b). The 0.00-0.05 m layer showed a more distinct $\mathrm{Kr}$ among the treatments, where C20 presents the highest values in all suctions, followed by M20, P20 and NF. In the 0.05-0.10 m layer, it can be seen the formation of two groups where the higher Kr were in C20 and M20, and P20 and NF formed a lower Kr group. In the 0.10-0.20 m layer, the treatments presented similar $\mathrm{Kr}$. 


\section{CONCLUSION}

The use of manure from swine and poultry did not increase the soil organic carbon content during the 20 years of application. The most intense soil use system (M20) was the one with the lowest carbon content, mainly in the 0-0.05 m layer.

The addition of swine and poultry manure under the conditions studied increased the water storage at higher stresses compared to the forest soil. TOC positively influenced water retention in mangrove areas, confirming the importance of organic carbon in the aggregation and maintenance of soil porosity.

\section{REFERENCES}

AGNE, S.A.A.; KLEIN, V.A. 2014. Matéria orgânica e atributos físicos de um Latossolo Vermelho após aplicações de dejeto de suínos. Revista Brasileira de Engenharia Agrícola e Ambiental, Campina Grande, v. 18, n. 7, p. 720-726.

ARATANI, R.G.; FREDDI, O.S.; CENTURION, J.F. ANDRIOLI, I. 2009. Qualidade física de um Latossolo Vermelho acriférrico sob diferentes sistemas de uso e manejo. Revista Brasileira de Ciência do Solo, Viçosa, v.33, p.677-687.

ARAÚJO, A.S.F.; LIMA, L.M.; MELO, W.J.; SANTOS, V.M.; ARAÚJO, F.F. 2016. Soil properties and cowpea yield after six years of consecutive amendment of composted tannery sludge. Acta Scientiarum. Agronomy, Maringá, v. 38, n. 3, p. 407-413.

ARAÚJO, M.A; TORMENA, C.A \& SILVA, A.P. 2004. Propriedades físicas de um Latossolo Vermelho distrófico cultivado e sob mata nativa. Revista Brasileira de Ciência do Solo, Viçosa, v. 28, p.337-345.

BARBOSA, G.M.C; OLIVEIRA, J.F.; MIYAZAWA, M; RUIZ, D.B.; TAVARES FILHO, J. 2015. Aggregation and clay dispersion of an Oxisol treated with swine and poultry manures. Soil \& Tillage Research, Amsterdam, v.146, p.279-285.

BONO, J.A.M.; MACEDO, M.C.M.; TORMENA, C.A.; NANNI, M.R.; GOMES, E.P.; MÜLLER, M.M.L. 2012. Infiltração de água no solo em um Latossolo vermelho da região sudoeste dos cerrados com diferentes sistemas de uso e manejo. Revista Brasileira de Ciência do Solo, Viçosa, v. 36, p. 1845-1853.

BORDIN I.; NEVES C.S.V.J.; MEDINA C.C.; SANTOS J.C.F.; TORRES E.; URQUIGA S. 2008. Matéria seca, carbono e nitrogênio de raízes de soja e milho em plantio direto e convencional. Pesquisa Agropecuária Brasileira. Brasília, v. 43, p. 1785-1792.

CELIK, I.; GUNAL, H.; BUDAK, M.; AKPINAR, C. 2010. Effects of long-term organic and mineral fertilizers on bulk density and penetration resistance in semi-arid Mediterranean soil conditions. Geoderma, Amsterdam, v. 160, n. 2, p. 236-243.

CARLESSO, R. 1995. Absorção de água pelas plantas: água disponível versus água extraível e a produtividade das culturas. Ciência Rural, Santa Maria, v. 25, n.1, p.83-188.

DOURADO NETO, D.; JONG VAN LIER, Q.; BOTREL, T.A.; LIBARDI, P.L. 1990. Programa para confecção da curva de retenção de água no solo utilizando o modelo de Genuchten. Engenharia Rural, Piracicaba, v. 1, p. 92-102. 
EMBRAPA. Centro Nacional de Pesquisa em solos. 1997. Manual de Métodos de Análise de Solo. Rio de Janeiro, 212p.

FATMA. Fundação de Meio Ambiente de Santa Catarina. 2000. Instrução Normativa IN-11. Suinocultura. Portaria Intersetorial n01/04, de 02.08.2000. Florianópolis: FATMA. 11p.

FERREIRA, D.F.; CARGNELUTTI FILHO, A.; LÚCIO, A.D. 2012. Procedimentos estatísticos em planejamentos experimentais com restrições na casualização. Sociedade Brasileira de Ciência do Solo. Boletim Informativo, Viçosa, v. 37, n. 03, p. 15-19.

HATI, K.M.; MANDAL, K.G.; MISRA, A.K.; GHOSH, P.K. \& BANDYOPADHYAY, K.K. 2006. Effect of inorganic fertilizer and farmyard manure on soil physical properties, root distribution, and water-use efficiency of soybean in Vertisols of central India. Bioresource Technology, Bhopal, v. 97, p. 2182-2188.

ISLABÃO, G.O.; LIMA, C.L.R.; VAHL, L.C.; TIMM, L.C.; TEIXEIRA, J.B.S. 2016. Hydrophysical properties of a typic hapludult under the effect of rice husk ash. Revista Brasileira de Ciência do Solo, Viçosa, v. 40, p. 150-161.

OLIVEIRA, D.M.S.; LIMA, S.P.; JAN VERBURG, E.E. 2015. Qualidade física do solo sob diferentes sistemas de manejo e aplicação de dejeto líquido suíno. Revista Brasileira de Engenharia Agrícola e Ambiental, Campina Grande, v.19, p. 280-285.

PORTUGAL, A.F.; JUCKSCH, I.; SCHAEFER, C.E.G.R.; WENDLING, B. 2008. Determinação de estoques totais de carbono e nitrogênio e suas frações em sistemas agrícolas implantados em Argissolo Vermelho-amarelo. Revista Brasileira de Ciência do Solo. Viçosa, v. 32, p. 20912100.

RAMOS, B.Z.; PAIS, P.S.M.; FREITAS, W.A.; D. JUNIOR, M.S. 2013. Avaliação dos atributos físico-hídricos em um Latossolo Vermelho distroférrico sob diferentes sistemas de manejoLavras/Minas Gerais/Brasil. Revista de Ciências Agrárias, Lisboa, v.36, p.340-346.

REICHARDT, K.; TIMM, L.C. 2004. Solo, planta e atmosfera: conceitos, processos e aplicações. São Paulo: Manole, 478 p.

REYNOLDS, W.D.; BOWMAN, B.T.; DRURY, C, F, TAN, C.S.; LU. X. 2002. Indicators of good soil physical quality: density and storage parameters. Geoderma, Amsterdan, v.110, p. 131146.

SCHERER, E.E.; NESI, C.N.; MASSOTTI, Z. 2010. Atributos químicos do solo influenciados por sucessivas aplicações de dejetos suínos em áreas agrícolas de Santa Catarina. Revista Brasileira de Ciência do Solo, Viçosa, v. 34, p.1375-1383.

SCHERER, E.E.; BALDISSERA, I. T.; DIAS, L.F.X. 1995. Caracterização e avaliação do potencial fertilizante do esterco líquido de suínos da Região Oeste Catarinense. Agropecuária Catarinense, Florianópolis, v.8, p. 35-39.

SHI, Y.; ZHAO, X.; GAO, X.; ZHANG, S.; WU, P. 2016.The effects of long-term fertilizer applications on soil organic carb on and hydraulic properties of a loess soil in China. Land Degradation \& Development, Chichester, v. 27, n. 1, p. 60-67.

SHI, X.H.; YANG, X.M.; DRURY, C.F.; REYNOLDS, W.D.; MCLAUGHLIN, N.B.; ZHANG, X.P. 2012. Impact of ridge tillage on soil organic carbon and selected physical properties of a clay loam in southwestern Ontario. Soil \& Tillage Research, Amsterdam, v.120, p.1-7.

TEDESCO, M.J.; GIANELLO, C.; BISSANI, C.A.; BOHNEN, H.; WOLKWEISS, S.J. 1995. Análises de solo, plantas e outros materiais. 2.ed. Porto Alegre: Universidade Federal do Rio Grande do Sul, 174p. 
VAN GENUCHTEN, M. Th. 1980. A closed-form equation for predicting the hydraulic conductivity of unsaturated soils. Soil Science Society of America Journal, Madison, v. 44, p. 892-898.

ZALUSKI, P. ANTONELI, V. 2014. Variabilidade na Infiltração da Água no Solo em área de Cultivo de Tabaco na Região Centro-Sul do Paraná. Caderno de Geografia PUC. Belo Horizonte, v. 24, n. 41. 